\title{
Chronic subdural haematoma: a review of 114 cases
}

\author{
M A L C OL M M. CA MER O N \\ From the Department of Neurological Surgery, Salford Royal Hospital, Salford
}

SU M M ARY One hundred and fourteen consecutive adult patients treated surgically for chronic subdural haematoma are described and their clinical features presented in detail. The diagnostic investigations are evaluated and a regime of surgical management is described. The three main modes of clinical presentation and the diagnostic role of carotid angiography are emphasised. It is suggested that the neurological state at the time of operation has no bearing on the prognosis and that, in particular, patients presenting in coma have a much better prognosis than might be expected. The average follow-up period was two years and the longest 11 years.

The most widely accepted views on the aetiology and evolution of chronic subdural haematoma have been well summarised recently (Araki, 1974; Sato and Suzuki, 1975). Aspects of the epidemiology, histology, and pathophysiology of these haematomas have been reported in several papers (Putnam and Cushing, 1925; Weir, 1971; Brodersen and Gjerris, 1975; Fogelholm and Waltimo, 1975). However, with the exception of two communications (McKissock et al., 1960; Loew and Kivelitz, 1976), relatively little attention has been paid to the clinical presentation, diagnostic investigations, and prognosis.

\section{Patients and methods}

A 25 year retrospective review revealed 114 adult patients shown at operation to have chronic subdural haematomas. Initially an attempt was made to classify patients into either subacute or chronic groups according to their histories. Those patients with a history of symptoms or an interval from known head injury of less than three weeks were considered subacute and those longer than three weeks, chronic. Tables 1 and 2 show various data of these two groups. However, in some patients the length of history was uncertain, and in others no relevant history could be obtained, and it proved unhelpful, in terms of clinical presentation and prognosis, to attempt to maintain the separation. Therefore, it was decided that the finding at operation of a black fluid surface collection over one or

Address for reprint requests: Department of Neurological Surgery Salford Royal Hospital, Chapel Street, Salford M60 9EP.

Accepted 30 March 1978
Table 1 Some features of 114 patients with subdural haematoma

\begin{tabular}{llll}
\hline $\begin{array}{l}\text { Total patient group } \\
\text { (114) }\end{array}$ & $\begin{array}{l}\text { Subacute } \\
(44)\end{array}$ & $\begin{array}{l}\text { Chronic } \\
(70)\end{array}$ & $\begin{array}{l}\% \text { of } \\
\text { total }\end{array}$ \\
\hline Male & 26 & 56 & 72 \\
Female & 18 & 14 & 28 \\
Average age & 56 & 56 & - \\
History of head injury & 32 & 40 & 63 \\
Fluctuation in symptoms or signs & 7 & 21 & 24 \\
In coma by the time of surgery & 12 & 3 & 13 \\
Bilateral haematomas evacuated & 1 & 12 & 11 \\
\hline
\end{tabular}

Table 2 Most common clinical findings in 114 patients with subdural haematoma

\begin{tabular}{lccc}
\hline Clinical finding & Subacute & Chronic & $\begin{array}{c}\% \text { of } \\
\text { total }\end{array}$ \\
\hline Hemiparesis (45 patients) & & & 40 \\
$\quad$ ipsilateral to haematoma & 11 & 7 & 16 \\
$\quad$ contralateral to haematoma & 10 & 17 & 24 \\
Personality or intellectual change & 11 & 23 & 30 \\
Papilloedema (23 patients) & 1 & 6 & 20 \\
$\quad$ with headache and vomiting & 2 & 7 & 6 \\
$\quad$ with hemiparesis & 4 & 3 & 6 \\
$\quad$ with coma & 12 & 3 & 13 \\
Coma (15 patients) & 5 & 1 & 5 \\
Unilateral pupillary dilatation & & & 38 \\
Headache (48 patients) & & & 5 \\
$\quad$ with other neurological findings & & & \\
$\quad$ alone & & & \\
\hline
\end{tabular}

both hemispheres would define that patient as a chronic subdural haematoma case. The age distribution of the patients is shown in Fig. 1.

\section{AETIOLOGY}

A direct head injury was identified in $63 \%$ of patients (Table 3 ). Of the remaining 42 patients, six were known epileptics, four were documented alcoholics, and two were receiving anticoagulant 


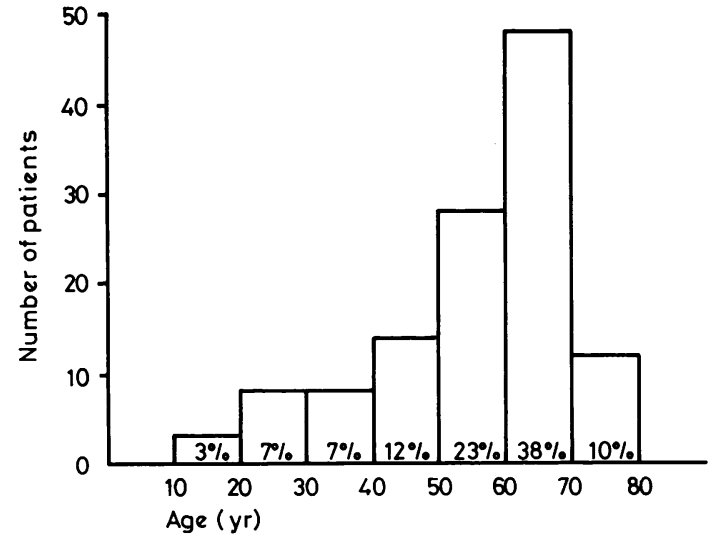

Fig. 1 Age distribution of 114 patients with chronic subdural haematoma. The youngest patient was 16 years and the oldest 79 years.

Table 3 Probable precipitating factors

\begin{tabular}{llr}
\hline Precipitating factors & $\begin{array}{l}\text { Cases } \\
\text { Number }\end{array}$ & $\%$ \\
\hline Direct head injury & 72 & 63 \\
Fall to the sitting position & 3 & 2 \\
Epilepsy & 6 & 5 \\
Alcoholism & 4 & 3 \\
Anticoagulant therapy & 2 & 2 \\
Severe sneezing & 1 & 1 \\
Severe coughing & 1 & 1 \\
Strain at heavy lifting & 1 & 1 \\
Shunted hydrocephalus & 1 & 1 \\
None identified & 23 & 20 \\
\hline
\end{tabular}

therapy. A fall to the sitting position, perhaps producing indirect cerebral trauma, coincided with the onset of symptoms in a further three patients and, similarly, severe bouts of coughing and sneezing appeared to be precipitating factors in another two patients. One further patient had had a ventriculoatrial shunt inserted previously for normal pressure hydrocephalus. No causative or precipitating factors could be identified in the remaining $20 \%$ of patients.

\section{SYMPTOMS AND SIGNS}

Ninety-two per cent of patients fell into three groups of symptomatology: hemiparesis, personality or intellectual change, and the features of raised intracranial pressure (Table 2). Some of these patients showed evidence of more than one group of symptoms but the majority signalled with only one element. The remaining $8 \%$ of patients presented either in coma with no reliable history, or with headache alone. Many patients had been mistakenly diagnosed as having cerebrovascular disease, psychiatric disorder, or brain tumour, and those patients with a known history of head injury were not diagnosed any sooner than those without this alerting signal. The 13 patients who had bilateral haematomas had an average duration of symptoms of 63 days (compared with 45 days for all 114 patients), and an average age of 63 years (compared with 56 years).

Hemiparesis was the most common abnormal neurological sign and it was contralateral to the haematoma in $60 \%$ of patients, whereas unilateral pupillary dilatation (seen in six patients) was always on the side of the haematoma. Personality or intellectual change was a more common presentation than were the features of raised intracranial pressure. Twenty-three patients showed papilloedema but only seven of these had the classical triad of headache, vomiting, and papilloedema.

Fifteen patients were in coma (no verbal response and no better than a flexion response in the limbs to painful stimuli) by the time of operation. They had an average age of 61 years, and 14 of them had an average duration of symptoms of only 16 days. The remaining patient, a 35 year old female with bilateral haematomas, had an unusually long history of five months after a fall from a motor cycle. Twelve patients in this coma group had had a head injury, and in four cases consciousness had been lost for longer than two hours.

Six patients had a fracture on plain skull radiographs, and in each of them the haematoma was contralateral to the fracture. Of these patients, three presented with headache and dysphasia, one with headache and third nerve palsy, one with personality disturbance, and one with coma. Three of these patients had lost consciousness at the time of their head injury and two of them died after operation.

Less than half of all patients $(43 \%)$ experienced headache and in $5 \%$ of patients it was the only symptom.

\section{INVESTIGATIONS}

Eighty-two per cent of patients had plain skull radiographs available for review and six skull fractures were found. Ten patients had radioactive technetium brain scans, and three of these examinations were falsely negative. Forty-three per cent of patients had been investigated by lumbar puncture before admission to the Neurosurgical Department, and review of this group showed no correlation between the CSF protein content or manometry and the symptoms or signs of raised intracranial pressure. No patient appeared to deteriorate within 12 hours of lumbar puncture. Computed tomography (CT) was available for only 
the last three patients in this series. In two of them unilateral hypodense haematomas were found. The other showed no abnormality, but repeat CT a week later showed bilateral hypodense collections.

One hundred and two patients were examined by bilateral carotid angiography and the correct diagnosis was revealed in all but one. Of the 12 patients who did not have angiography, six had extreme clinical states and were submitted directly to surgery, four had clearly positive technetium scans, one had air encephalography, and one ventriculography. The films in these last two patients were mistakenly interpreted as showing frontal tumour, and the subdural haematomas were found at craniotomy.

\section{TREATMENT}

One hundred and twelve patients had similar surgical management. Two burrholes were made over each haematoma, and complete evacuation was aided by saline irrigation. If the brain failed to achieve satisfactory spontaneous re-expansion, isotonic saline was injected by lumbar puncture with the dura still open. This was considered necessary in $40 \%$ of patients, and the volume of saline injected ranged from 40 to $350 \mathrm{ml}$. Two patients had elective craniotomy for presumed frontal tumour after air contrast examination. Three patients required burrhole reopening for evacuation of further haematoma.

\section{Results}

Table 4 shows the results of surgical treatment assessed by patient review in the outpatient clinic and by spouse interview. The average follow-up period was two years and the longest 11 years. Detailed psychometric testing was not performed.

One hundred and nine patients $(96 \%)$ were alive at the average follow-up time of two years. One hundred and one of these patients had made a complete recovery within six weeks of surgery, 83 of them doing so within one week. The remaining eight survivors $(7 \%)$ were unimproved by evacuation of their haematomas (Table 5), and the five patients who died are shown in Table 6 . No patient remained in a deteriorated state after operation.

Table 4 Results of surgical treatment

\begin{tabular}{lcc}
\hline Result & $\begin{array}{l}\text { Cases } \\
\text { Number }\end{array}$ & $\%$ \\
\hline $\begin{array}{l}\text { Complete recovery } \\
\quad \text { within seven days of surgery }\end{array}$ & 83 & 73 \\
$\quad$ within six weeks of surgery & 101 & 89 \\
Unimproved at average interval of three months & 8 & 7 \\
$\quad$ from surgery & 0 & 0 \\
Survived in a deteriorated state & 5 & 4 \\
Died & & \\
\hline
\end{tabular}

Table 5 Details of the eight unimproved survivors

\begin{tabular}{|c|c|c|c|c|}
\hline Sex & $\begin{array}{l}\text { Age } \\
(y r)\end{array}$ & $\begin{array}{l}\text { History } \\
\text { of trauma }\end{array}$ & $\begin{array}{l}\text { Clinical } \\
\text { presentation }\end{array}$ & $\begin{array}{l}\text { Clinical features at three } \\
\text { months from surgery }\end{array}$ \\
\hline $\mathbf{F}$ & 30 & Yes & $\begin{array}{l}\text { Dysphasia and } \\
\text { headache }\end{array}$ & Dysphasia \\
\hline $\mathbf{M}$ & 43 & Yes & $\begin{array}{l}\text { Progressive } \\
\text { hemiparesis }\end{array}$ & Hemiparesis \\
\hline $\mathbf{M}$ & 44 & Yes & $\begin{array}{l}\text { Progressive } \\
\text { hemiparesis }\end{array}$ & Personality disorder \\
\hline $\mathbf{M}$ & 55 & Yes & Coma & Severe personality disorder \\
\hline $\mathbf{M}$ & 66 & Yes & Hemiparesis & Personality disorder \\
\hline $\mathbf{F}$ & 68 & Yes & $\begin{array}{l}\text { Progressive } \\
\text { hemiparesis }\end{array}$ & Hemiparesis \\
\hline $\mathbf{M}$ & 70 & Yes & Dementia & Dementia \\
\hline $\mathbf{M}$ & 71 & Yes & $\begin{array}{l}\text { Dysphasia and } \\
\text { diplopia }\end{array}$ & Dysphasia \\
\hline
\end{tabular}

COMPLICATIONS OF OPERATION

One burrhole became infected, resulting in a subdural abscess, but there was a good recovery at three months, and one 34 year old male required CSF shunting for communicating hydrocephalus 10 years after haematoma evacuation.

All of the six known epileptics in this series had an increase in fit frequency after operation. One other patient developed early postoperative seizures confined to the first week, and two further patients developed generalised seizures at one and 10 years respectively. Another four patients, not previously known to be epileptic, experienced preoperative seizures after the onset of their symptoms but none of them had epilepsy after operation. Thus, 13 patients $(11 \%)$ experienced generalised seizures at some stage. None of these patients died.

\section{Discussion}

Putnam and Cushing (1925) were the first to draw attention to the difficulty of diagnosis in chronic subdural haematoma, and they emphasised the varying symptomatology. The present review

Table 6 Details of the five patients who died

\begin{tabular}{|c|c|c|c|c|c|}
\hline Sex & $\begin{array}{l}\text { Age } \\
(y r)\end{array}$ & $\begin{array}{l}\text { History } \\
\text { of trauma }\end{array}$ & $\begin{array}{l}\text { Clinical } \\
\text { presentation }\end{array}$ & $\begin{array}{l}\text { Findings at } \\
\text { necropsy }\end{array}$ & $\begin{array}{l}\text { Post- } \\
\text { operative } \\
\text { day of death }\end{array}$ \\
\hline $\mathrm{F}$ & 52 & No & $\begin{array}{l}\text { Personality } \\
\text { change }\end{array}$ & $\begin{array}{l}\text { Internal } \\
\text { capsule } \\
\text { haemorrhage }\end{array}$ & 1 \\
\hline $\mathbf{M}$ & 67 & Yes & $\begin{array}{l}\text { Raised intra- } \\
\text { cranial pressure }\end{array}$ & $\begin{array}{l}\text { Myocardial } \\
\text { infarction }\end{array}$ & 8 \\
\hline $\mathbf{F}$ & 69 & No & $\begin{array}{l}\text { Personality } \\
\text { change }\end{array}$ & $\begin{array}{l}\text { Massive } \\
\text { pulmonary } \\
\text { embolus }\end{array}$ & 9 \\
\hline $\mathbf{F}$ & 70 & Yes & $\begin{array}{l}\text { Raised intra- } \\
\text { cranial pressure }\end{array}$ & $\begin{array}{l}\text { Massive } \\
\text { pulmonary } \\
\text { embolus }\end{array}$ & $0^{*}$ \\
\hline $\mathbf{M}$ & 71 & Yes & Hemiparesis & $\begin{array}{l}\text { Acute } \\
\text { pulmonary } \\
\text { oedema }\end{array}$ & 4 \\
\hline
\end{tabular}

*The pulmonary embolus on day 0 occurred in theatre as the haematoma was being evacuated. 
shows that $92 \%$ of patients had an approximately equal incidence of three modes of presentation: hemiparesis, personality or intellectual change, and the features of raised intracranial pressure. Fluctuation in the conscious level or other neurological signs was not a prominent feature in this series and was seen in only $24 \%$ of patients.

Bilateral carotid angiography under general anaesthesia provided the correct diagnosis in all but one of the 102 patients so examined (Figs. 2 and 3 ). The exception was early in the series, and the films were of poor quality. Ten patients had technetium brain scans and falsely negative results were seen in three in whom subsequent carotid angiography revealed subdural haematomas. The number of patients who showed falsely positive technetium scans and who were submitted to burrhole exploration with negative results is not known. Of the three patients in this series examined by CT, two showed unilateral hypodense collections and the other initially showed no abnormality. This inability of CT to show certain sub-

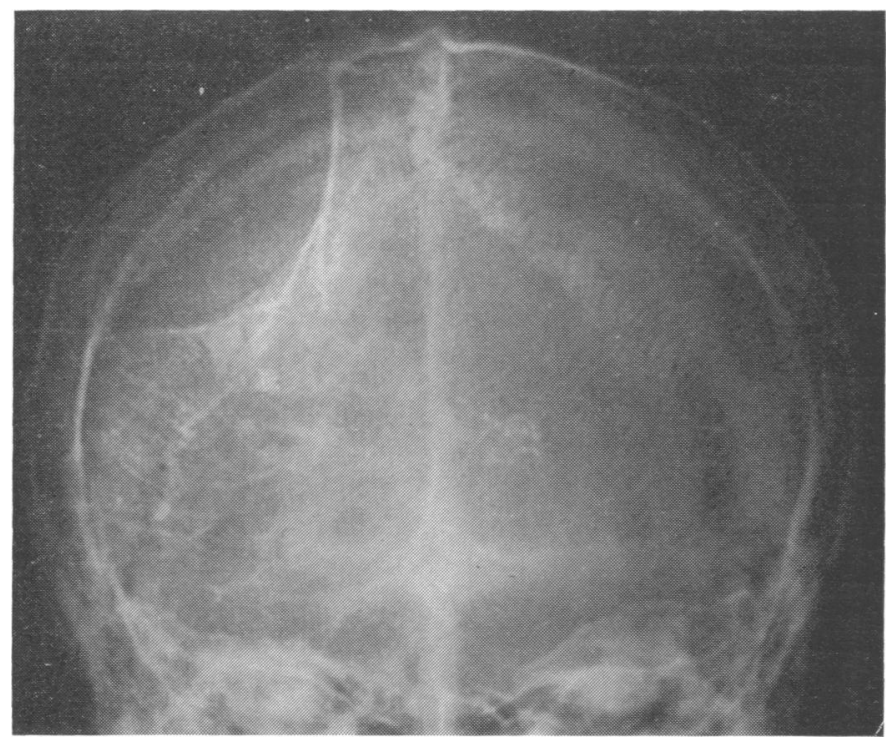

Fig. 2 Right carotid angiogram, venous phase, showing deep surface collection and midline venous shift. Positive pressure lumbar puncture was required at surgery.

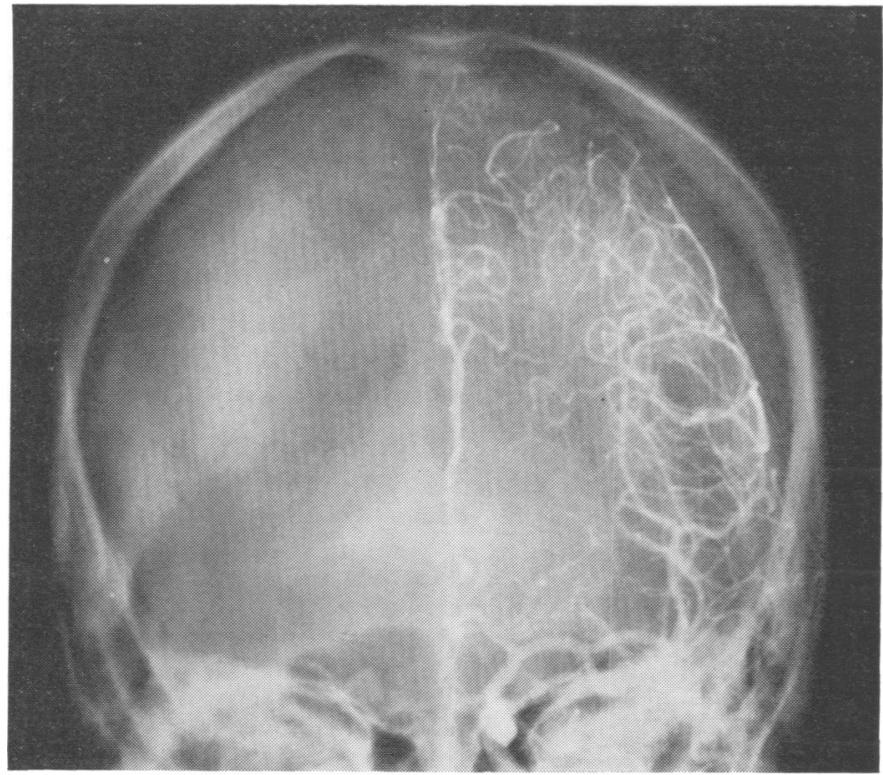

Fig. 3 Left carotid angiogram showing a surface collection and no significant midline arterial shift. Right carotid angiography showed a similar sized haematoma on the right. Positive pressure lumbar puncture was not required at surgery. 
dural haematomas was first reported by Ambrose (1973) and further discussed by Scotti et al. (1977).

A variety of different treatments for chronic subdural haematoma have been advocated. Craniotomy and membranectomy were considered necessary by Robinson (1955), while Svien and Gelety (1964) suggested that burrhole evacuation of the liquid haematoma alone was superior to craniotomy. Tabaddor and Shulman (1977) compared these two surgical treatments with twist-drill craniostomy and closed-system drainage in a total of 71 patients, and demonstrated the last method to produce the best results. Non-surgical treatment with bedrest and mannitol therapy was advocated by Bender and Christoff (1974) and by Suzuki (1974) but debated by Gjerris and Schmidt (1974).

In the present series 112 patients had burrhole evacuation as the treatment of choice. The remaining two patients had craniotomy for supposed frontal tumour. The results in this series, compared with those in some other published series, are shown in Table 7.

Apart from the three patients who were returned to theatre for burrhole reopening and evacuation of further haematoma, none of the 109 survivors deteriorated postoperatively. At operation it was considered necessary, in $40 \%$ of patients, to inject saline by lumbar puncture to encourage the brain to come up to the dura. This may have contributed to the absence of that postoperative condition often called the low pressure state.

There was no significant difference in the average age of patients in each of the three main groups of clinical presentation: hemiparesis, 56 years; personality or intellectual change, 59 years; features of raised intracranial pressure, 54 years. The remaining 11 patients, who presented with headache alone or in coma with no history available, had an average age of 55 years.

No prognostic criteria emerged from this review, and the neurological state of the patient at the time of surgery seemed to have no bearing on the

Table 7 Outcome from surgical treatment of patients with chronic subdural haematoma in some published series

\begin{tabular}{lclc}
\hline Author & $\begin{array}{l}\text { Total } \\
\text { number } \\
\text { of cases }\end{array}$ & $\begin{array}{l}\text { Unimproved } \\
\text { or worse }\end{array}$ & Deaths \\
\hline McKissock et al. (1960) & 307 & 35 & 31 \\
Plum and Posner (1973) & 73 & $*$ & 14 \\
Fogelholm et al.(1975) & 109 & $*$ & 1 \\
Tabaddor and Shulman & 71 & 18 & 15 \\
(1977) & 114 & 8 & 5 \\
\hline
\end{tabular}

*Information not given in article quoted. prognosis. Of the 15 patients in coma at the time of surgery, one died, one was unimproved, and 13 made complete recoveries. Twelve patients in this coma group had a history of head injury, and all eight unimproved survivors (average age 56 years) also had a history of head injury.

\section{Conchusion}

The outcome from surgical treatment by burrhole evacuation, for patients with chronic subdural haematoma, is uninfluenced by their age, mode of presentation, or neurological state at the time of surgery. Surgical treatment by simple burrhole evacuation, plus positive pressure saline lumbar puncture in some patients, can give a very high rate of complete recovery to normal life.

\section{References}

Ambrose, J. (1973). Computerised transverse axial scanning (tomography). Part 2. Clinical application. British Journal of Radiology, 46, 1023-1047.

Araki, C. (1974). Recent Progress in Neurological Surgery, p. 14. Excerpta Medica: Amsterdam. American Elsevier: New York.

Bender, M. B., and Christoff, N. (1974). Non-surgical treatment of subdural haematomas. Archives of Neurology (Chicago), 31, 73-79.

Brodersen, P., and Gjerris, F. (1975). Regional cerebral blood flow in patients with chronic subdural haematomas. Acta Neurologica Scandinavica, 51, 233-239.

Fogelholm, R., and Waltimo, O. (1975). Epidemiology of chronic subdural haematoma. Acta Neurochirurgica (Wien), 32, 247-250.

Fogelholm, R., Heiskanen, O., and Waltimo, O. (1975). Chronic subdural haematoma in adults. Influence of patients age on symptoms signs and thickness of haematoma. Journal of Neurosurgery, 42, 43-46.

Gjerris, F., and Schmidt, K. (1974). Chronic subdural haematoma. Surgery or mannitol treatment. Journal of Neurology, 40, 639-642.

Loew, F., and Kivelitz, R. (1976). Subdural Haematoma. In Handbook of Clinical Neurology. Vol. 24, part 2, p. 297. Edited by P. J. Vinken and G. W. Bruyn. North-Holland Publishing Company: Amsterdam.

McKissock, W., Richardson, A., and Bloom, W. H. (1960). Subdural haematoma. A review of 389 cases. Lancet, 1, 1365-1369.

Plum, F., and Posner, B. J. (1973). Diagnosis of Stupor and Coma. F. A. Davis Company: Philadelphia.

Putman, T. J., and Cushing, H. (1925). Chronic subdural haematoma. Its pathology, its relation to pachymeningitis haemorrhagica and its surgical treatment. Archives of Surgery, 11, 329-393.

Robinson, R. G. (1955). The treatment of subacute and chronic subdural haematomas. British Medical Journal, 1, 21-22. 
Sato, S., and Suzuki, J. (1975). Ultrastructural observations of the capsule of chronic subdural haematoma in various clinical states. Journal of Neurosurgery, 43, 569-578.

Scotti, G., Terbrugge, K., Melancon, D., and Belanger, G. (1977). Evaluation of the age of subdural haematomas by computerised tomography. Journal of Neurosurgery, 47, 311-315.

Suzuki, J. (1974). Mannitol treatment of subdural haematomas. Journal of Neurosurgery, 41, 785-786.

Svien, H. J., and Gelety, J. E. (1964). On the surgical management of encapsulated subdural haematoma. A comparison of the results of membranectomy and simple evacuation. Journal of Neurosurgery, 21, 172-177.

Tabaddor, K., and Shulman, K. (1977). Definitive treatment of chronic subdural haematoma by twistdrill craniostomy and closed-system drainage. Journal of Neurosurgery, 46, 220-226.

Weir, B. (1971). The osmolality of subdural haematoma fluid. Journal of Neurosurgery, 34, 528-533. 